\title{
Human rights advances in women's reproductive health in Africa
}

\author{
Charles G. Ngwena ${ }^{\mathrm{a}, *}$, Eunice Brookman-Amissah ${ }^{\mathrm{b}}$, Patty Skuster ${ }^{\mathrm{c}}$ \\ a Centre for Human Rights, Faculty of Law, University of Pretoria, Pretoria, South Africa \\ b Ipas, Nairobi, Kenya \\ C Ipas, Chapel Hill, NC, USA
}

\begin{abstract}
A b s t r a c t
\end{abstract}
The African Commission on Human and Peoples' Rights recently adopted General Comment No 2 to interpret provisions of Article 14 of the Protocol to the African Charter on the Rights Women. The provisions relate to women's rights to fertility control, contraception, family planning, information and education, and abortion. The present article highlights the General Comment's potential to promote women's sexual and reproductive rights in multiple ways. The General Comment's human rights value goes beyond providing states with guidance for framing their domestic laws, practices, and policies to comply with treaty obligations. General Comment No 2 is invaluable in educating all stakeholders-including healthcare providers, lawyers, policymakers, and judicial officers at the domestic level-about pertinent jurisprudence. Civil society and human rights advocates can use the General Comment to render the state accountable for failure to implement its treaty obligations.

Keywords:

Abortion ; Contraception ; Family planning ; Fertility control ; Human rights ; Reproductive health ; Sexual health

\section{Introduction}

The Protocol to the African Charter on Human and Peoples' Rights on the Rights of Women in Africa (henceforth, the Protocol) [1] is a binding multilateral treaty at the African regional level. It was adopted by the African Union on July 11, 2003, pursuant to Article 66 of the African Charter on Human and Peoples' Rights (henceforth, the African Charter) [2], and came into force on November 25, 2005. Its overarching purpose is to consolidate and advance women's rights at the African regional level with a view to achieving equality between the sexes. Its juridical aim is substantive equality, nondiscrimination, and human dignity for women and girls within a framework that not only emphasizes respect and protection of human rights, but also encourages their promotion and fulfillment at the domestic level. To date, the Protocol has been ratified by more than two-thirds of the 54 member states of the African Union [3].

The African Commission on Human and Peoples' Rights (henceforth, the African Commission) adopted the Protocol as more than just a supplement to the African Charter. It is the fruit of advocacy by women's organizations in the African region [4]. Through the Protocol, the African Commission responded to widespread concern about the lack of effective protection of African women's human rights [5]. There was a realization that despite African states' ratification of treaties and international

\footnotetext{
* Corresponding author at: Centre for Human Rights, Faculty of Law, University of Pretoria, Private Bag X20, Hatfield 0028, Pretoria, South Africa. Tel.: + 2712 4203034; fax: +27123625125 .

E-mail address: charlesngwena@gmail.com (C.G. Ngwena).
}

human rights instruments based on the African Charter, including the Convention on the Elimination of All Forms of Discrimination against Women (CEDAW), their protection of women's rights at the domestic level remained weak or nonexistent in many sectors [1].

The Protocol's wide protections extend to social, political, and economic spheres to provide holistic protection of women's human rights. It contains 32 substantive provisions, such as Article 14, which enjoins states to ensure the realization of the right to health of women, including sexual and reproductive health. The aim of the present paper is to comment on the significance of General Comment No 2 on Article 14 (1) (a), (b), (c) and (f) and Article 14 (2) (a) and (c) of the Protocol [6] in terms of promoting the objects of the Protocol and in particular promoting the sexual and reproductive health and rights of women. The General Comment was adopted by the African Commission at its 55th Ordinary Session, which was held in Luanda, Angola, between April 28 and May 12, 2014 [7]. The General Comment interprets provisions of Article 14 of the Protocol-which guarantee women's rights to fertility control, contraception, family planning education and abortion-stating that:

1. Parties shall ensure that women's right to health, including sexual and reproductive health, is respected and promoted, including:

(a) the right to control fertility;

(b) the right to decide whether to have children, the number of children and the spacing of children;

(c) the right to choose any method of contraception;

(d) the right to self-protection and to be protected against sexually transmitted infections, including HIV/AIDS;

(e) the right to be informed on one's health status and on the health status of one's partner-particularly if affected by 
sexually transmitted infections, including HIV/AIDS-in accordance with internationally recognized standards and practices;

(f) the right to have family planning education.

2. Parties shall take appropriate measures to:

(a) provide adequate, affordable, and accessible health services, including information, education, and communication programs to women, especially those in rural areas;

(b) establish and strengthen existing prenatal, delivery, and postnatal health and nutritional services for women during pregnancy and while they are breastfeeding;

(c) protect the reproductive rights of women by authorizing medical abortion in cases of sexual assault, rape, or incest, and when the continued pregnancy endangers the mental and physical health of the mother or the life of the mother or the fetus.

\section{Rationale of the General Comment}

Primarily, general comments are authoritative interpretive guidance issued by the UN or regional treaty bodies to aid states in their implementation of human rights treaties. General comments are quasijudicial guidance to help states to achieve treaty objectives. Through general comments, treaty bodies clarify the nature and extent of the normative content of ratifying states' treaty obligations. By clarifying the obligations of the state as a duty-bearer, general comments necessarily also clarify the corresponding rights conferred on individuals as rights-holders. Although they do not constitute binding law, general comments can be invaluable in promoting the objectives of a treaty, especially when they seek to clarify treaty obligations in areas that are novel and for which there are no precedents, or that are historically morally contested or stigmatized. General comments are particularly important for providing interpretive guidance in areas where human rights remain unprotected as is the case with women's reproductive health, especially safe abortion care.

Under the African Charter system, the adoption of general comments falls under the mandate of the African Commission, under Article 45 of the African Charter [2]. Article 45(1)(b) of the African Charter gives the African Commission the mandate to "formulate and lay down principles and rules aimed at solving problems relating to human rights." The African Commission must provide guidance to African states to help them to comply with their treaty obligations, including through domestic legislation. The African Commission's adoption of general comments should be understood in this light. It is a process that serves to complement rather than supplant the mandate of the African Court on Human and Peoples' Rights, which is otherwise charged with matters of interpretation arising out of the application or implementation of the Protocol [1].

In the history of the human rights system based on the African Charter, the General Comment on Article 14 (1) (a), (b), (c) and (f) and Article 14 (2) (a) and (c) of the Protocol [6] represents only the second general comment adopted by the African Commission. The African Commission first adopted a General Comment in 2012 on Article 14 (1) (d) and (e) of the Protocol [8], clarifying the provisions relating to the rights of women to protection against sexually transmitted infections, including HIV/AIDS. At a more general level, the adoption of General Comment No 2 signals the continuation of a new trend in the history of the African Commission whereby equality between the sexes and elimination of all forms of discrimination against women is given priority. The Commission is working to ensure that women can fully realize the sexual and reproductive rights guaranteed by the Protocol [6]. More specifically, the General Comment is informed by African states' urgent need to respond to the human rights challenges of unmet sexual and reproductive health needs of women in the African region and particularly contraception and safe abortion.

Although the provisions of Article 14 of the Protocol guaranteeing rights to contraception/family planning are not entirely novel, such rights are nonetheless easily undermined at the domestic level. States can neglect these issues. Laws, administrative procedures, stigma, and sociocultural and religious practices present barriers to service that undermine women's decision-making power over their sexual and reproductive health.

As the General Comment observes, the proportion of women who do not have access to modern contraception in the African region remains high when compared with other regions. In Africa, adolescent girls and women who are poor, have little or no education, and live in rural areas fare the worst [6]. A study conducted by the Guttmacher Institute and the United Nations Population Fund [9] found that the number of women with unmet contraceptive need in Sub-Saharan Africa increased from 31 million in 2008 to 36 million in 2012. Even when compared with other low-income regions, Africa has a greater proportion of women with unmet contraceptive need [9]. One of the consequences of unmet contraception need is a commensurately high rate of unintended pregnancies, including adolescent pregnancies. Women with unintended pregnancies resort to unsafe abortion, resulting in a higher rate of maternal mortality and morbidity [6]. In a region where many countries have weak healthcare systems and women have poor access to obstetric services, states must meet contraceptive needs so as to reduce unwanted pregnancies and preventable maternal mortality and morbidity. Against this backdrop, the African Commission's adoption of General Comment No 2 is opportune in seeking to clarify and underline state obligations in a sphere in which there is manifest need.

Furthermore, the African Commission's step in clarifying the abortion provisions of Article 14 is important because the Protocol is groundbreaking as the first human rights treaty to expressly recognize abortion as a discrete and substantive human right [10]. Partly on account of the stigma and controversy that surrounds abortion and its historical criminalization, there has been a trend in the African region for more liberal abortion laws to remain unimplemented or administratively inaccessible. Healthcare professionals, women seeking abortion, and legal professionals are not aware of the abortion laws, even when the laws permit access to safe abortion services [11]. But it is not only the lack of political commitment that undermines the realization of sexual and reproductive rights. As the Special Rapporteur on the Rights of Women in Africa, Commissioner Soyata Maiga has observed, where a treaty such as the Protocol ushers in a new regime of human rights, noncompliance with treaty obligations can also be the result of benign ignorance about requisite human rights standards [8].

Although unsafe abortion is a preventable cause of maternal mortality and morbidity, it remains pernicious in Sub-Saharan Africa. Globally, the number of deaths from unsafe abortion reduced from 69000 in 1990 to 56000 in 2003, and 47000 in 2008. However, the African region is lagging behind [12]. Unsafe abortion accounts for $13 \%$ of maternal mortality in Sub-Saharan Africa [12]. The region carries a disproportionate burden of unsafe abortion; close to $62 \%$ of unsafe abortion-related mortality (29 000 women) globally occurs in the African region [12]. Thus, denial or lack of safe abortion services is a cause of immeasurable distress for women and could violate thousands of women's right to life. Indeed, the persistence of preventable mortality and morbidity from unsafe abortion is an important impetus for the adoption of General Comment No 2 [6]. Therefore, the need to raise awareness and provide education about these new human rights cannot be overemphasized. Given adequate political commitment, General Comments can become a source of important guidance to legislators and policymakers on how to implement abortion laws in ways that facilitate access to safe abortion services.

\section{Clarifying state obligations}

Because of limitation of space, it is not possible to comment exhaustively on the provisions of the General Comment here; its normative 
salience will be highlighted in terms of the main juridical approaches that it uses to clarify state obligations.

The General Comment comprises five sections and 63 paragraphs [6]: the introduction (paragraphs 1-11), the background section (paragraphs 12-22), and three other sections that explain state obligations under Article 14. The three other sections deal with normative content (paragraphs 23-40), general obligations of the state (paragraphs 41-45), and the specific obligations of the state (paragraphs 46-63). What stands out in all the five sections is that the General Comment does not set out to invent new jurisprudence but rather to draw explicitly as well as implicitly from existing international human rights law and authoritative guidance. The General Comment clarifies obligations of the state in ways that build on existing human rights standards developed under UN treaties such as the International Covenant on Civil and Political Rights, the International Covenant on Economic, Social and Cultural Rights, and the CEDAW [6] (paragraph 30).

In respect of utilizing existing international standards when addressing sexual and reproductive health, at the outset, the General Comment "reaffirms" the normative content of the right to health [6] (paragraph 6) as interpreted by the Committee on Economic, Social and Cultural Rights (CESCR) in General Comment 14 [13]. In many respects, General Comment No 2 can be understood as a concrete application of the normative framework of the right to health that was developed in General Comment 14 to the specific contexts of the rights to fertility control, contraception, family planning education, and abortion that are guaranteed to women under the Protocol. In this way, the General Comment consolidates international human rights best practices in an African regional context.

Drawing from CESCR General Comment No 14 [13] (paragraph 12), General Comment No 2 throughout premises the right to contraception/family planning and abortion on the state obligation to ensure access to reproductive health services that are available, accessible, ethically and culturally acceptable, and of good quality. General Comment No 2 employs "accessibility" as a holistic normative concept. Accessibility in the General Comment is informed by a notion of substantive equality. It requires the state to ensure access to health services on a nondiscriminatory basis and in ways that are physically accessible, economically accessible, and in which information is accessible, as intended under General Comment 14. Throughout, General Comment No 2 also adopts a similar approach when using the concepts of availability, acceptability, and good quality so that their regional application is also in line with authoritative interpretation of international law, including General Comment 14.

General Comment No 2 underscores the interdependence and indivisibility of rights such that the civil and political rights components of sexual and reproductive rights cannot be separated from the socioeconomic components. All state obligations are couched in terms of the obligations to respect, protect, promote, and fulfil the rights guaranteed to women by the Protocol. The obligations to promote and fulfil are particularly important as many African states presently sit with laws and policies that have not been implemented. States are obliged to attend not just to barriers in law and policy but also the cultural, social, religious, and economic barriers that can stand in the way of women fulfilling their rights [6] (paragraph 44). Sensitizing and educating communities, religious leaders, traditional and political leaders on sexual and reproductive rights as well as training healthcare professionals is part of how the state ought to fulfil its obligations in the light of stigma associated with contraception and abortion in particular [6] (paragraph 45). Ultimately, the state must fulfil its duty by allocating sufficient and available resources [6] (paragraph 45). The General Comment's ultimate focus on fulfillment of state obligations reflects Article 26 of the Protocol, which enjoins States to adopt all necessary measures and in particular provide budgetary resources for the "full and effective implementation" of the rights guaranteed by the Protocol.

In many respects, by clarifying state obligations relating to fertility control, contraception, and family planning, the General Comment reinforces interpretive guidance issued by other treaty bodies such as the Committee on CEDAW, including the duty to ensure access to requisite services on a nondiscriminatory basis and without impediment by third parties [14]. However, the General Comment expands these concepts with respect to abortion in ways that could otherwise remain unknown by policymakers, courts, human rights defenders, and civil society in general. This is because of the novelty of an express acknowledgment of abortion as a human right under the Protocol.

It is particularly significant to note that, in its conceptualization of "health", General Comment No 2 [6] (paragraphs 7, 38) reflects the WHO definition of a holistic concept of health as "a state of complete physical, mental and social well-being and not merely the absence of disease or infirmity" [15]. The General Comment further clarifies state obligations by drawing guidance from the technical guidelines and standards that have been issued by WHO in its publication "Safe abortion: technical and policy guidance for health systems" [16] when interpreting abortion provisions of the Protocol [6] (paragraph 10).

One of the areas in which the General Comment clarifies the abortion provisions of Article 14 is in explicating how abortion grounds should be understood. Drawing from the technical guidance of WHO, the General Comment explains, for instance, that when applying a holistic understanding of health as a ground for abortion, the woman's reasons must be taken into account [6] (paragraph 38). Furthermore, where risk to "mental health" is relied upon, it is not necessary to first establish psychiatric evidence [6] (paragraph 38). Because nearly half of African states permit abortion on the ground of the pregnant woman's health [17], this clarification is potentially enabling in most African countries where there are no precedents. The General Comment clarifies that states have the duty to remove restrictions that are not necessary for providing safe abortion services such as the requirements of multiple signatures, approval by committees before an abortion can be performed, or restricting performance of abortion to only medical practitioners [6] (paragraph 58). Where there are not enough doctors -as in most countries in Africa-states should enable midlevel providers such as midwives to perform procedures for which they can be trained to perform competently and safely [6] (paragraph 58).

\section{Conclusion}

General Comment No 2 of the African Commission is timely and at the threshold of a new international development agenda that has women's reproductive health and rights as an important and recurring theme. We hope that it will assist African countries to better understand their obligations to women in this critical but relatively unfamiliar area of health and to provide the know-how to interpret and implement reproductive health services related to contraception and safe legal abortion in the quest to improve the sexual and reproductive rights of women in the region.

\section{Conflict of interest}

The authors were part of the group convened to assist the African Commission in developing the General Comment through the Office of the Special Rapporteur on the Rights of Women in Africa.

\section{References}

[1] African Commission on Human and Peoples' Rights. Protocol to the African Charter on Human and Peoples' Rights on the Rights of Women in Africa. http://www. achpr.org/files/instruments/women-protocol/achpr_instr_proto_women_eng.pdf. Published 2003. Accessed January 28, 2015.

[2] Organization of African Unity. African (Banjul) Charter on Human and Peoples' Rights. http://www.achpr.org/files/instruments/achpr/banjul_charter.pdf. Published 1981. Accessed January 28, 2015.

[3] African Commission on Human and Peoples' Rights. Ratification Table: Protocol to the African Charter on Human and Peoples' Rights on the Rights of Women in Africa. http://www.achpr.org/instruments/women-protocol/ratification/. Accessed January 28, 2015. 
[4] Banda F. Women, law and human rights: an African perspective. Oxford: Hart; 2005 66-82.

[5] Viljoen F. An introduction to the Protocol to the African Charter on Human and Peoples' Rights on the Rights of Women in Africa. Wash Lee J Civ Rights Soc Justice 2009;16:11-46.

[6] African Commission on Human and Peoples' Rights. General Comment No 2 on Article 14 (1) (a), (b), (c) and (f) and Article 14 (2) (a) and (c) of the Protocol to the African Charter on Human and Peoples' Rights on the Rights of Women in Africa, Adopted by the African Commission on November 28, 2014. http://www. achpr.org/files/instruments/general-comments-rights-women/achpr_instr_general_ comment2_rights_of_women_in_africa_eng.pdf. Accessed February 10, 2015.

[7] The African Commission on Human and Peoples' Rights. Final communiqué of the 55th Ordinary Session of the African Commission on Human and People's Rights. http://www.achpr.org/files/sessions/55th/info/communique55/achpr_fico_2014_ eng.pdf. Accessed January 4, 2015.

[8] African Commission on Human and Peoples' Rights. General Comments on Article 14 (1) (d) and (e) of the Protocol to the African Charter on Human and Peoples Rights on the Rights of Women in Africa. http://www.achpr.org/instruments/generalcomments-rights-women/. Accessed January 4, 2015.

[9] Singh S, Darroch JE. Adding it up: costs and benefits of contraceptive services-estimates for 2012. http://www.guttmacher.org/pubs/AIU-2012-estimates.pdf. Published June 2012. Accessed January 28, 2015.

[10] Ngwena CG. Inscribing abortion as a human right: significance of the Protocol on the Rights of Women in Africa. Hum Rights Q 2010;32(4):783-864.
[11] Ngwena CG. Reforming African abortion laws and practice: the place of transparency. In: Cook RJ, Dickens BM, Erdman JN, editors. Abortion Law in Transnational Perspective: Cases and Controversies. Philadelphia, PA: University of Pennsylvania Press; 2014. p. $166-86$.

[12] World Health Organization. Unsafe abortion: global and regional estimates of the incidence of abortion and associated mortality in 2008. Geneva: World Health Organization; 2011.

[13] UN Economic and Social Council. General Comment No 14: The Right to the Highest Attainable Standard of Health. http://www.refworld.org/docid/4538838d0.html. Published 11 August, 2000. Accessed January 28, 2015.

[14] UN Committee on the Elimination of Discrimination Against Women. CEDAW General Recommendation No. 24: Article 12 of the Convention (Women and Health). http://www.refworld.org/docid/453882a73.html. Published 1999. Accessed January 28, 2015.

[15] World Health Organization. Constitution of the World Health Organization. http:// www.who.int/governance/eb/who_constitution_en.pdf. Published October 2006. Accessed January 28, 2015.

[16] World Health Organization. Safe abortion: technical and policy guidance for health systems. 2nd ed. Geneva: World Health Organization; 2012.

[17] Centre for Reproductive Rights. The world's abortion laws 2014. http:// reproductiverights.org/sites/crr.civicactions.net/files/documents/AbortionMap2014. PDF. Published July 2014. Accessed January 5, 2015. 